\title{
Hubungan antara Nilai Red Cell Distribution Width dan Fungsi Ventrikel Kiri pada Anak dengan Penyakit Jantung Bawaan Asianotik
}

Achmad Yudha AP, Sri Lilijanti Widjaja, Harsono Salimo

Bagian Ilmu Kesehatan Anak Fakultas Kedokteran Universitas Sebelas Maret/RS. Dr. Moewardi, Surakarta

Latar belakang. Abnormalitas fungsi sistolik dan diastolik dari ventrikel kanan dan kiri banyak ditemukan pada pasien dengan PJB asianotik. Di Indonesia, fasilitas untuk menilai fungsi ventrikel kiri berupa ekokardiografi tidak selalu tersedia di rumah sakit perifer sehingga diperlukan penanda lain sebagai alternatif, di antaranya, red cell distribution width (RDW).

Tujuan. Menganalisis hubungan nilai RDW dan fungsi ventrikel kiri (ejeksi fraksi, fraksi pemendekan dan rasio E/A) pada anak dengan PJB asianotik di RSUD Dr. Moewardi Surakarta.

Metode. Penelitian observasional analitik dengan desain cross sectional, subjek 33 anak PJB asianotik. Hubungan antara kadar RDW dan parameter fungsi ventrikel kiri dianalisis menggunakan uji korelasi Spearman.

Hasil. Di antara 33 subjek terdapat 17 laki-laki (51,5\%). Didapatkan jenis PJB asianotik VSD (ventricle septal defect) 10 pasien (30,3\%), ASD (atrial septal defect) 15 pasien (45,5\%) dan PDA (patent ductus arteriosus) 8 pasien (24,2\%). RDW berkorelasi signifikan dengan rasio E/A pada PJB asianotik secara keseluruhan ( $\mathrm{r}-0,342 ; \mathrm{p}=0,026)$. Pada VSD dan PDA, RDW tidak berkorelasi dengan parameter fungsi ventrikel kiri apapun. Namun pada ASD, RDW berkorelasi signifikan dengan ejeksi fraksi $(\mathrm{r}-0,491 ; \mathrm{p}=0,032)$.

Kesimpulan. Didapatkan hubungan antara RDW dengan parameter fungsi ventrikel kiri, terutama rasio E/A pada pasien PJB asianotik. Selain itu, juga terdapat hubungan antara RDW dengan ejeksi fraksi pada pasien ASD. Sari Pediatri 2017;18(5):339-44

Kata kunci: red cell distribution width, fungsi ventrikel kiri, PJB asianotik

\section{Relationship between The Value of Red Cell Distribution Width and Left Ventricular Function in Children with Acyanotic Congenital Heart Disease}

Achmad Yudha AP, Sri Lilijanti Widjaja, Harsono Salimo

Background. Systolic and diastolic function abnormalities of the right and left ventricles are commonly found in patients with acyanotic CHD . In Indonesia, echocardiography examination to assess left ventricular function is not always available in peripheral hospitals, hence we need an alternative marker such as red cell distribution width (RDW).

Objective. To analyze the relationship between RDW values and left ventricular function (ejection fraction, shortening fraction and E/A ratio) in children with acyanotic congenital heart disease in Dr. Moewardi Hospital, Surakarta.

Method. This is an analytical observational study with cross sectional design in 33 acyanotic congenital hearth disease children. The relationship between RDW values and parameters of left ventricular function were analyzed using Spearman correlation test.

Results. Of the 33 subjects there were 17 (51.5\%) male. Acyanotic CHD consisted of: ventricular septal defect (VSD) 10 patients (30.3\%), atrial septal defect (ASD) 15 patients (45.5\%), and patent ductus arteriosus (PDA) 8 patients (24.2\%). Overall, the RDW value significantly correlated with the $\mathrm{E} / \mathrm{A}$ ratio in cyanotic CHD patients $(\mathrm{r}-0.342 ; \mathrm{p}=0.026)$. In VSD and PDA, RDW is not correlated with any of left ventricular function parameters. However, in ASD, RDW significantly correlated with ejection fraction ( $\mathrm{r}-0.491 ; \mathrm{p}=0.032$ ).

Conclusion. We found a relationship between RDW and the parameters of left ventricular function, especially the E/A ratio, in patients with acyanotic CHD. We also found a relationship between RDW with ejection fraction in patients with ASD. Sari Pediatri 2017;18(5):339-44

Keywords: red cell distribution width, left ventricular function, acyanotic CHD

Alamat korespondnesi: Dr. Achmad Yudha AP, Dr. Sri Lilijanti Widjaja SpA(K). Bagian Ilmu Kesehatan Anak Fakultas Kedokteran Universitas Sebelas Maret, RS. Dr. Moewardi Surakarta. E-mail: achmadyudha_ap@yahoo.com 
$\mathrm{P}$ enyakit jantung bawaan (PJB) merupakan penyakit jantung yang sudah didapat sejak lahir. Terbagi 2 macam tipe, yaitu PJB non sianotik dan sianotik. Jenis PJB asianotik paling banyak diderita adalah ventricular septal defect (VSD), atrial septal defect (ASD), dan patent ductus arteriousus (PDA).

Angka kejadian penyakit jantung bawaan di Indonesia adalah 8 tiap 1000 kelahiran hidup. ${ }^{2}$ Angka kelahiran di Indonesia tahun 2013 adalah 4,8 juta jiwa, ${ }^{3}$ diperkirakan jumlah penderita penyakit jantung bawaan pada tahun 2015 sekitar 300.000 - 400.000 kasus. Prevalensi VSD, ASD, dan PDA menempati urutan terbanyak PJB asianotik, masing-masing 35\%, 35\%, dan $33 \% .^{1}$ Penyakit jantung bawaan dapat menyebabkan terjadinya gagal jantung. Gagal jantung pada anak sebesar $10 \%$ pasien, $6 \%$ terjadi pada pasien PJB dan $80 \%$ pada kardiomopati. ${ }^{4}$ Gagal jantung ini dapat disebabkan dari adanya disfungsi ventrikel kiri. Evaluasi dan monitoring fungsi ventrikel kiri perlu dilakukan agar tidak terjadi gagal jantung yang lebih parah. ${ }^{5}$

Di Indonesia, fasilitas untuk menilai fungsi ventrikel kiri pada PJB, seperti pemeriksaan ekokardiografi, tidak selalu tersedia di rumah sakit perifer sehingga diperlukan penanda lain sebagai alternatif yang mudah diakses dan murah. Pemeriksaan laboratorium, pencitraan, dan tanda-tanda klinis merupakan tiga kategori terbanyak yang digunakan dalam estimasi prognosis gagal jantung. ${ }^{6,7}$ Pemeriksaan red cell distribution width (RDW) sebagai bagian dari pemeriksaan hematologi rutin.

Red cell distribution width merupakan pengukuran variasi dalam ukuran eritrosit (anisositosis). Kadar RDW yang meningkat pada orang dewasa berhubungan dengan peningkatan risiko semua penyebab dan mortalitas kardiovaskular pada pasien dengan gagal jantung dan penyakit kronis lainnya. ${ }^{8,9}$ Sampai saat ini, banyak studi pada populasi dewasa telah meneliti nilai prognostik RDW untuk gagal jantung, tetapi hasilnya tidak konsisten ${ }^{10}$ dan belum terdapat penelitian di ranah anak.

Pada penelitian Felker $\mathrm{dkk},{ }^{8}$ peningkatan RDW dapat menjadi prediktor kuat dari peningkatan morbiditas dan mortalitas pada pasien dengan gagal jantung kronis. Selain itu, kadar RDW dengan cutoff point sebesar $16,4 \%$ secara signifikan berkorelasi dengan parameter ekokardiografi, seperti fraction shortening (FS), A velocity, rasio E/A, dan tidak berkorelasi E. velocity dan rasio E/E'. Penelitian lain oleh $\mathrm{Oh} \mathrm{dkk}^{11}$ melaporkan korelasi yang signifikan antara RDW dan parameter ekokardiografi, seperti E. velocity dan rasio E/E. Penelitian ini bertujuan untuk menganalisis hubungan kadar RDW dan fungsi ventrikel kiri pada pasien PJB asianotik.

\section{Metode}

Penelitian cross sectional (potong lintang) yang berlangsung di Bagian KSM Ilmu Kesehatan Anak UNS-RSUD dr. Moewardi kota Surakarta, antara Agustus - Oktober 2016.

Subyek adalah pasien anak dengan diagnosis PJB asianotik yang datang berobat (kontrol) atau rawat inap di Bagian Kardiologi Anak Rumah sakit Dr. Moewardi Surakarta. Kriteria inklusi adalah anak usia 1-18 tahun yang didiganosis dengan PJB asianotik, belum menjalani operasi koreksi PJB, dan orang tua atau wali menandatangani inform consent penelitian. Kritria eksklusi adalah semua pasien dengan PJB yang disertai sepsis atau gizi buruk atau gangguan/kelainan hati, pasien PJB yang disertai thalasemia dan sakit kritis. Pada penelitian ini subjek yang dipakai adalah 30 anak yang didapat secara metode konsekutif.

Penelitian ini telah mendapatkan persetujuan dari komite etik penelitian FK UNS. Data meliputi identitas pasien, nama, nomer rekam medis, usia, jenis kelamin, diagnosis, data laboratorium berupa $\mathrm{Hb}$ dan RDW serta data ekokardiografi fungsi ventrikel kiri. Pengukuran kadar RDW dilakukan bersamaan dengan pemeriksaan darah rutin di Laboratorium Patologi Klinik RSDM Surakarta menggunakan ADVIA 2120 hematology system dan dilakukan pemeriksaan ekokardiografi menggunakan Vivid $i$ ultrasound. Pemeriksaan ekokardiografi ini untuk menilai fungsi ventrikel kiri melalui parameter ejeksi fraksi (normal $>60 \%$ ), fraksi pemendekan (30\%), dan rasio E/A (> 1 detik).

Karakteristik dasar subyek (usia, jenis kelamin, jenis PJB asianotik) dideskripsikan dalam persentase dan rerata. Analisis statistik dilakukan dengan program SPSS 17.0 menggunakan uji statistik korelasi Pearson. Nilai p dianggap bermakna secara statistik jika $<0,05$.

\section{Hasil}

Total 33 subyek penelitian, 17 (51,5\%) anak lelaki dan $16(48,5 \%)$ perempuan. Berdasarkan jenis PJB 
Tabel 1. Karakteristik dasar subyek penelitian

\begin{tabular}{lcc}
\hline Variabel & $\mathrm{f}(\%)$ & Rerata \pm SB \\
\hline Jenis kelamin & & \\
$\quad$ Laki-laki & $17(51,5)$ & \\
$\quad$ Perempuan & $16(48,5)$ & \\
Status nutrisi & & \\
$\quad$ Baik & $28(84,8)$ & \\
Kurang & $5(15,2)$ & \\
Jenis PJB asianotik & & \\
VSD & $10(30,3)$ & \\
ASD & $15(45,5)$ & \\
PDA & $8(24,2)$ & \\
NYHA & & \\
I & $14(42,4)$ & \\
II & $19(57,6)$ & \\
Parameter laboratorium & & \\
Hb (g/dL) & & $12,61 \pm 1,99$ \\
RDW (\%) & & $14,88 \pm 1,71$ \\
Parameter ekokardiografi & & \\
EF (\%) & & $71,64 \pm 7,96$ \\
FS (\%) & & $40,49 \pm 8,36$ \\
E/A & & $1,23 \pm 0,50$ \\
\hline
\end{tabular}

Tabel 2. Korelasi antara RDW dengan parameter fungsi ventrikel kiri

\begin{tabular}{lcc}
\hline Korelasi & $\mathrm{r}$ & $\mathrm{p}$ \\
\hline RDW vs EF & $-0,201$ & 0,131 \\
RDW vs FS & 0,011 & 0,475 \\
RDW vs E/A & $-0,342$ & $0,026^{*}$ \\
\hline
\end{tabular}

Keterangan: ${ }^{*} \mathrm{p}<0,05$ artinya korelasi signifikan. asianotik didapatkan VSD $10(30,3 \%)$, ASD 15 (45,5\%), dan PDA 8 (24,2\%) anak. Karakteristik dasar subyek penelitian tertera pada Tabel 1 . Hubungan antara RDW dengan parameter fungsi ventrikel kiri dianalisis dengan teknik korelasi bivariat. Hasil perhitungan koefisien korelasi dan uji statistiknya tertera pada Tabel 2.

Berdasarkan Tabel 2 diketahui bahwa RDW berkorelasi signifikan dengan rasio E/A $(p=0,026)$, tetapi tidak berkorelasi signifikan dengan $\mathrm{EF}(\mathrm{p}=0,131)$ dan juga tidak berkorelasi signifikan dengan FS $(\mathrm{p}=0,475)$. Koefisien korelasi antara RDW dengan rasio E/A bernilai negatif menunjukkan bahwa kedua variabel memiliki hubungan berbanding terbalik, semakin tinggi RDW maka semakin rendah rasio E/A.

Hubungan antara RDW dan parameter fungsi ventrikel kiri dibagi menurut jenis PJB asianotik dianalisis bivariat (Tabel 3). Pada pasien PJB asianotik jenis VSD dan PDA, RDW tidak berkorelasi signifikan dengan parameter fungsi ventrikel kiri apapun. Pada pasien PJB asianotik jenis ASD, RDW berkorelasi signifikan dengan EF ( $\mathrm{p}=0,032)$.

\section{Pembahasan}

Penelitian ini dilakukan dengan pemeriksaan ekokardiografi (EKG) untuk menilai parameter fungsi ventrikel kiri dan pemeriksaan RDW pada 33 anak dengan PJB asianotik yang memenuhi kriteria inklusi dan eksklusi. Total 33 subyek yang terdiri atas 17

Tabel 3. Korelasi antara RDW dengan parameter fungsi ventrikel kiri menurut pembagian jenis PJB asianotik

\begin{tabular}{lccc}
\hline PJB Asianotik & Korelasi & $\mathrm{r}$ & $\mathrm{p}$ \\
\hline VSD & RDW vs EF & 0,045 & 0,451 \\
& RDW vs FS & $-0,103$ & 0,388 \\
ASD & RDW vs E/A & 0,119 & 0,372 \\
$(\mathrm{n}=15)$ & RDW vs EF & $-0,491$ & $0,032^{*}$ \\
& RDW vs FS & $-0,206$ & 0,231 \\
PDA & RDW vs E/A & $-0,372$ & 0,086 \\
$(\mathrm{n}=8)$ & RDW vs EF & $-0,231$ & 0,291 \\
& RDW vs FS & 0,064 & 0,440 \\
\hline
\end{tabular}

Keterangan:* $\mathrm{p}<0,05$ artinya korelasi signifikan. 
(51,5\%) pasien laki-laki dan $16(48,5 \%)$ perempuan. Tidak didapatkan data khusus angka kejadian PJB asianotik, tetapi hasil penelitian ini selaras dengan pernyataan Nikyar dkk $^{12}$ yang melaporkan angka kejadian PJB terbanyak terjadi pada laki-laki. Menurut Alabdulgader ${ }^{14}$ dan Stephensen dkk, ${ }^{13}$ angka kejadian PJB sama pada laki-laki dan perempuan, sedangkan Marielli $\mathrm{dkk}^{15}$ melaporkan bahwa kejadian PJB di Kanada lebih banyak pada anak perempuan (52\%).

Berdasarkan jenis, PJB asianotik terbagi menjadi ASD 15 (45,5\%), VSD 10 (30,3\%), dan PDA 8 $(24,2 \%)$ pasien. Hasil ini serupa dengan penelitian lain di Iran dan Indonesia yang melaporkan jenis PJB yang paling banyak ditemukan adalah $\mathrm{ASD}^{16}$ sementara pada penelitian lainnya adalah VSD. ${ }^{13,17}$ Hasil pemeriksaan laboratorium dan EKG menunjukkan bahwa sampel memiliki rerata RDW 14,88\%, EF $71,64 \%$, FS 40,49\%, dan rasio E/A 1,23.

Hubungan RDW dengan parameter fungsi ventrikel kiri dianalisis dengan teknik korelasi bivariat. Hasil analisis bivariat tersebut, RDW berkorelasi bermakna dengan rasio E/A, tetapi tidak berkorelasi bermakna dengan EF dan FS. Koefisien korelasi antara RDW dengan rasio E/A merupakan korelasi lemah dan bernilai negatif yang menunjukkan bahwa kedua variabel memiliki hubungan berbanding terbalik, semakin tinggi RDW maka semakin rendah rasio E/A. Hal ini serupa dengan hasil penelitian dari Mawlana $\mathrm{dkk}^{18}$ yang melaporkan bahwa RDW berkorelasi secara bermakna dengan rasio E/A dan fraksi pemendekan (FS) (cutoff point 16,4\%), tetapi tidak berkorelasi dengan LVEDD, LVESD, dan E/É.

Hasil perhitungan korelasi antara RDW dengan parameter fungsi ventrikel kiri pada tiap-tiap kelompok sampel yang dibagi menurut jenis PJB asianotik. Pada pasien PJB asianotik jenis VSD dan PDA, RDW tidak berkorelasi bermakna dengan parameter fungsi ventrikel kiri apapun. Pada pasien PJB asianotik jenis ASD, RDW berkorelasi bermakna dengan EF. Koefisien korelasinya bernilai negatif, artinya, semakin tinggi RDW maka semakin rendah EF.

Atrial septal defect (ASD) akan mengakibatkan terjadinya overload volume jantung bagian kanan, peningkatan resistensi vaskular pulmonar, dan aritmia atrial. ${ }^{19,20}$ Pirau ASD akan menyebabkan underfilling dari ventrikel kiri dan overload volume dari ventrikel kanan yang akan mengganggu gerakan ventrikel. ${ }^{21,22}$ Oleh karena itu, pada pasien dengan pirau ASD yang cukup signifikan, ventrikel kanan akan melebar dan septumnya akan berdeviasi ke ventrikel kiri yang akan menyebabkan kompresi pada ventrikel kiri. ${ }^{23}$ Dengan kata lain, ASD mencerminkan suatu volume overload kronis dari ventrikel kanan yang pada akhirnya akan menyebabkan penurunan preload ventrikel kiri dengan cara menurunkan pengisian ventrikel yang dapat memengaruhi fungsi ventrikel kanan maupun kiri. ${ }^{24,25}$ Karena mekanisme tersebut, fungsi sistolik dan diastolik dapat terganggu secara mekanik, ${ }^{21}$ serta akan terjadi perubahan geometri ventrikel kiri yang akan berujung pada menurunnya ejeksi fraksi.

Hipertensi pulmonal merupakan komplikasi yang sering terjadi pada pirau kiri ke kanan. ${ }^{26}$ Proses terjadinya hipertensi pulmonal lebih banyak terjadi pada pirau dengan aliran darah ke paru yang berlebih dan bertekanan tinggi sehingga tekanan di paru sama dengan tekanan sistemik, seperti pada VSD, PDA, dan trunkus arteriosus. Namun begitu, dapat juga terjadi pada pirau kiri ke kanan dengan aliran darah ke paru yang berlebih dan tekanan rendah, seperti pada ASD. Pada pasien dengan PJB asianotik, peningkatan aliran darah ke paru akan memicu inflamasi dinding arteri pulmonalis sehingga akan terjadi hipertensi pulmonal. ${ }^{27}$ Dalam hal ini, tipe dan ukuran defek serta besarnya pirau merupakan faktor risiko yang penting, sekitar $50 \%$ VSD dengan defek yang besar dan 10\% ASD dapat berkembang menjadi hipertensi pulmonal. ${ }^{28}$ Patobiologis dari hipertensi pulmonal merupakan kondisi multifaktorial yang berperan penting adalah disfungsi endotel. Diduga, remodelling dari dinding areteri pulmonal, vasokonstriksi, inflamasi, dan trombosis akan menyebabkan peningkatan tahanan arteri pulmonal. ${ }^{29}$ Adanya inflamasi pada pasien PJB asianotik, terutama ASD, akan menyebabkan gangguan fungsi sistolik dan diastolik serta perubahan geometri ventrikel kiri yang akan berujung penurunan ejeksi fraksi pada ASD. Telah diketahui dari penelitian sebelumnya, bahwa inflamasi akan meningkatkan kadar RDW. Kami menyimpulkan bahwa terdapat hubungan antara RDW dengan ejeksi fraksi pada pasien dengan ASD.

Keterbatasan penelitian ini, antara lain, rentang usia pasien yang terlalu lebar dan pengambilan data hanya dilakukan satu kali. Tidak diperhitungkan juga lebar defek PJB asianotik, di mana VSD dan ASD merupakan defek dependen. Kami juga tidak membandingkan tingkat inflamasi yang terjadi dengan parameter lain selain RDW. Disimpulkan bahwa terdapat hubungan antara RDW dan fungsi ventrikel 
Achmad Yudha AP dkk: Hubungan antara nilai RDW dan fungsi ventrikel kiri pada anak dengan PJB asianotik

kiri pada anak dengan penyakit jantung bawaan asianotik.

\section{Daftar pustaka}

1. Hariyanto D. Profil penyakit jantung bawaan di instalasi rawat inap anak RSUP Dr. M. Djamil Padang Januari 2008-Februari 2011. Sari Pediatri 2012;14:152-7.

2. Allen HD, Franklin WH, Fontana ME. Congenital heart disease : untreated and operated. Dalam: Allen HD, Driscoll DJ, Shaddy RE, Feltes TF, penyunting. Moss and Adams' heart disease in infants, children and adolescents including the fetus and young adult. Edisi ke-8. Philadelphia: Lippincott Williams and Wilkins; 2012.h.657-64.

3. Kementerian Kesehatan Republik Indonesia. Profil kesehatan Indonesia tahun 2014. Jakarta: Kemkes; 2015.

4. Massin MM, Astadicko I, Dessy H. Epidemiology of heart failure in a tertiary pediatric center. Clin Cardiol 2008;31:38891.

5. Hunt SA, Abraham WT, Chin MH, Feldman AM. ACC/AHA 2005 guideline update for the diagnosis and management of chronic heart failure in the adult. A report of the American College of Cardiology/American Heart Association Task Force on practical guidelines. Diakses pada 30 Juni 2016. Didaat dari: www.accorg/qualityandscience/clinical/topic/topic.htm.

6. van Kimmenade RR, Mohammed AA, Uthamalingam S, van der Meer P, Felker GM, Januzzi JL Jr. Red blood cell distribution width and 1-year mortality in acute heart failure. Eur J Heart Fail 2010;12:129-36.

7. Thakur V, Fouron JC, Mertens L, Jaeggi ET. Diagnosis and management of fetal heart failure. Can J Cardiol 2013;29:75967

8. Felker GM, Allen LA, Pocock SJ. Red cell distribution width as a novel prognostic marker in heart failure: data from the CHARM program and the Duke databank. J Am Coll Cardiol 2007; 50:40e7.

9. Zöller B, Melander O, Svensson P, Engström G. Red cell distribution width for predicting cardiovascular disease: a literature review. EMJ Cardiol 2014;2:61-70.

10. Anderson JL, Ronnow BS, Horne BD. Usefulness of a complete blood count-derived risk score to predict incident mortality in patients with suspected cardiovascular disease. Am J Cardiol 2007; 99:169-74.

11. Oh J, Kang SM, Hong N. Relation between red cell distribution width with echocardiographic parameters in patients with acute heart failure. J Card Fail 2009;15:517-22.

12. Nikyar B, Sedehi M, Mirfazeli A, Qorbani M, Golalipour
MJ. Prevalence and pattern of congenital heart disease among neonates in Gorgan, Northern Iran (2007-2008). Iranian J Pediatrics 2011:307-12.

13. Stephensen SS, Sigfusson G, Eiriksson H, Sverrisson JT, Torfason B, Haraldsson A, dkk. Congenital cardiac malformations in Iceland from 1990. Cardiol Young 2004;14:396-401.

14. Alabdulgader AAA. Congenital heart disease in Saudi Arabia: current epidemiology and future projections. East Mediter Health J 2006;12:S157-67.

15. Marielli AJ, Mackie AS, Ionescu-Ittu R Rahme E, Pilote L. Congenital heart disease in general population changing prevalence aged distribution. Circulation 2007;115:163-7.

16. Rahim F, Ebadi A, Saki G. Prevalence of congenital heart disease in iran: a clinical study. J Med Sci 2008;8:547-52.

17. Xue-young Y, Xiao-feng L, Xiao-dong L, Ying-long L. Incidence of congenital heart disease in Beijing, China. Chin Med J 2009;122:1128-32.

18. Mawlana W, Donia A, Elamrousy D. Relation between red cell distribution width and left ventricular function in children with heart failure. ISRN Pediatrics 2014;1-4.

19. Campbell M. Natural history of atrial septal defect. Brit Heart J 1970;32: 820-6.

20. Samanek M. Children with congenital heart disease: probability of natural survival. Pediatric Cardiol 1992;13:152-8.

21. Popio KA, Gorlin R, Teichholz LE, Cohn PF, Bechtel D, Herman MV. Abnormalities of left ventricular function and geometry in adults with an atrial septal defect. Ventriculographic, hemodynamic and echocardiographic studies. Am J Cardiol 1975;36:302-8.

22. Bonow RO, Borer JS, Rosing DR, Bacharach SL, Green $\mathrm{MV}$, Kent KM. Left ventricular functional reserve in adult patients with atrial septal defect: pre- and postoperative studies. Circulation 1981;63:1315-22.

23. Kim SJ. Geometric and functional change of both ventricles after atrial ventricular septal defect closure. J Cardiovasc Ultrasound 2014;22:180-1.

24. Gomez CA, Ludomirsky A, Ensing GJ, Rocchini AP. Effect of acute changes in load on left ventricular diastolic function during device closure of atrial septal defect. Am J Cardiol 2005;95:686-8.

25. Schroha AM, Laghezzaa LB, Domíngueza PJ, Brandána V, Nentoa DE. Echocardiographic Doppler evaluation of ventricular function in children with an atrial septal defect. Rev Esp Cardiol 2008;61:595-601.

26. Badesch DB, Champion HC, Sanchez MA, $d k k$. Diagnosis and assessment of pulmonary arterial hypertension. J Am Coll Cardiol 2009;54:55-66.

27. Gursoy M, Salihoglu E, Hatemi AC, Hokenek AF, Ozkan 
S, Ceyran H. Inflammation and congenital heart disease associated pulmonary hypertension. Heart Surg Forum 2015;18:E38-41.

28. McLaughlin VV, Archer SL, Badesch DB. ACCF/AHA 2009 Expert consensus document on pulmonary hypertension: a report of the american college of cardiology foundation task force on expert consensus documents and the american heart association developed in collaboration with the american college of chest physicians; american thoracic society, inc.; and the pulmonary hypertension association. J Am Coll Cardiol 2009;53:1573-619.

29. De Luca G, Venegoni L, Iorio S. Platelet distribution width and the extent of coronary artery disease: results from a large prospective study. Platelets 2010;21:508-14. 